Dear Mother:

HdQrs. 48th USCI

Vicksburg, Miss., Oct. 28th, 1864

Yours of 16th inst is at hand announcing the sorrowful news of the death of dear little Lillace. She has only gone before us a short distance. When our time comes may we be as well prepared to go as she was. It is hard, very hard to part with her but we know she is better off than any of us. She has left a world of sin and sorrow, trials and troubles for one of endless happiness and pleasure. Why should we mourn and be unhappy. We must strive to meet her in that house where she lives. I had hoped to see her here on earth once more, but I always felt as though I never would. I cannot tell what impressed the idea on my mind.

... As soon as we are paid I will start for home. I have my leave. You need not write until you hear from me again. I am well. Your affectionate son,

B. F. Stevens

\title{
THE HOOVER-WALLACE CONTROVERSY DURING WORLD WAR I
}

\author{
by Donald L. Winters \\ Asst. Professor of American History \\ University of Northern lowa, Cedar Falls
}

In many respects, World War I was a difficult and trying time for Americans. Not only was the country involved in its first war abroad, but there were accompanying problems, tensions, and disagreements on the homefront. One such disagreement gave rise to a bitter conflict between an Iowan, Henry Cantwell Wallace, and a former Iowan, Herbert Clark Hoover. The controversy disrupted activities connected with the war effort and was to have repercussions later when both men were members of the cabinets of Warren G. Harding and Calvin Coolidge in the early 1920s.

Hoover, the son of a blacksmith and small dealer in agricultural machinery, was born in West Branch, Iowa, in 1874. Both parents, who were devout Quakers, died before 
the boy was 10, and he went to live with an uncle in Oregon. After graduating from Stanford University in 1895, he rapidly gained wealth and world-wide reputation as a mining engineer. The outbreak of war in Europe in 1914 found him living in England, from where the government of Belgium called him to serve as commissioner of its food relief program, a position in which Hoover gained acclaim for his administrative ability.

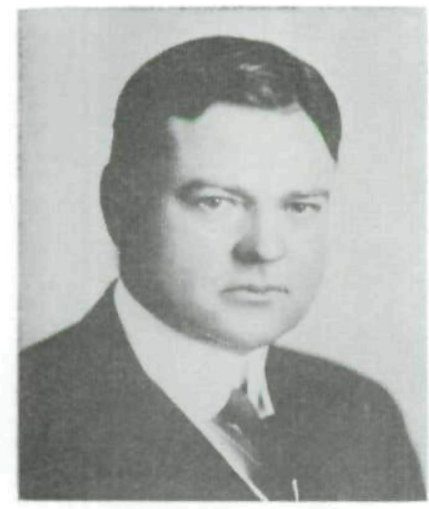

conrtesy Hoover Presidential Library

Herbert C. Hoover

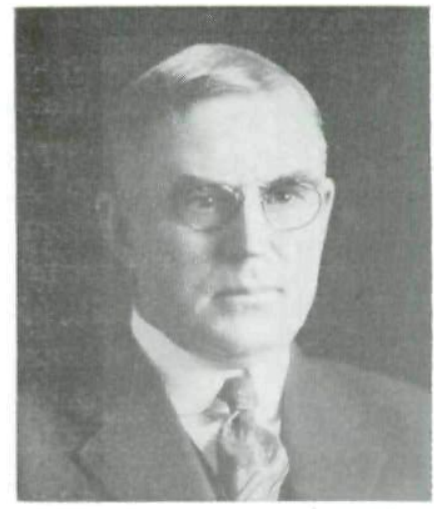

courtesy U.S.D.A.

Henry C. Wallace

Wallace, born in 1866 in Rock Island, Ill., moved with his family to Iowa in 1871. His father, affectionately called "Uncle Henry" by his friends, was a Presbyterian clergyman, but he left the ministry to take up light farming and later entered the field of agricultural journalism. Wallace graduated from Iowa State College (now Iowa State University) in Ames in 1893 and won appointment as assistant professor of dairying at his alma mater. Two years later he and his father established Wallaces' Farmer, which became one of the most influential agricultural journals in the Middle West. Besides serving as editor of the paper, Wallace was an active and prominent member of the Republican party and secretary of the Corn Belt Meat Producers' Association, the principal objective of which was to secure better transportation conditions for livestock shippers.

With the entry of the United States into the war in 1917, President Woodrow Wilson summoned Hoover from abroad 
and placed him at the head of the newly-created Food Administration. Charged with responsibility for supplying American and Allied forces with foodstuffs, the agency was given broad powers over the production and distribution of agricultural goods. Shortly after assuming his new position, Hoover appointed Wallace as chairman of a committee to advise the Administration on pork supply. Disagreement soon developed between the two men over policies designed to stimulate hog production.

When it became clear in the latter half of 1917 that the supply of pork was failing to meet mounting wartime demands, the Food Administration attempted to correct the deficiency through a propaganda campaign. Basing its approach on an appeal to rural patriotism, Hoover's office issued circulars and press releases to the effect that it was the farmers' duty to increase output. "Closing the gap in hog production ...." read one release, "is not only one of the big opportunities but one of the big obligations of American farmers. . . This is the immediate war duty of farmers." Along with efforts to increase production, the Food Administration also admonished the country as a whole to consume less meat.

Wallace, on the other hand, insisted that the approach of the Food Administration would not attain the desired result. "Appeals to the producer on the ground of patriotism," he lectured Hoover, "will not bring an adequate response." Convinced that production could be stimulated only by an "economic appeal," Wallace urged a solution based on a theory worked out by his oldest son. ${ }^{2}$ From a study he had made of the relationship between livestock and grain prices, Henry Agard Wallace concluded that the ratio of the market offering per 100 weight of hogs and that per bushel of corn had to equal or exceed 13.1 if production of pork were to be stimulated to the degree needed in 1917. As long as hog prices remained low in relation to corn, he explained, many farmers would find it more profitable to sell their corn rather than to feed

${ }^{1}$ Undated Press Release of the Food Administration, copy in Henry

C. Wallace Papers, University of Iowa Library, Iowa City, Box 4.

${ }^{2}$ Wallace to Hoover, Sept. 24, 1917, ibid., Box 1. 
it to livestock, and pork production would thus remain below the desired level. ${ }^{3}$ The "economic appeal" advanced by the older Wallace, therefore, was the one in which the Food Administration would guarantee hog prices based upon the formula derived by his son.

Wallace's personal friend, Gifford Pinchot, was a member if the Food Administration during the first months of the war. The two men had become acquainted through Uncle Henry, who had met Pinchot when both were serving on the Country Life Commission, a committee appointed by President Theodore Roosevelt in 1908 to study rural culture and life and to make recommendations for their preservation and improvement. Approximately of the same age, of similar views on many subjects, and possessing compatible personalities, Wallace and Pinchot soon struck up a close and lasting friendship. Pinchot explained their warm relationship and mutual respect, in part, as the product of a common admiration for Roosevelt, which "bound us in an intimate bond." As a result of both this friendship and an ingrained sympathy for agrarians, Pinchot sought to use his position on the Food Administration to gain adoption of Wallace's proposal for a ratio guarantee.

Hoover had little interest in the proposal and set himself firmly against it from the outset. At least part of the reason for his opposition stemmed from problems involved with the handling of a two-dollar-per-bushel minimum on wheat, for which his office had already been made responsible. Claiming that under the management of the Food Administration the minimum had in fact become a fixed maximum price, producers were highly critical of the agency. Small wonder, therefore, that Hoover was reluctant to consent to the establishment of still another guarantee. In addition, he wanted to limit as much as possible government interference in the economy.

${ }^{3}$ Henry A. Wallace, Agricultural Prices, Des Moines: Wallace Publishing Co., 1920, 28, 33-35. After the war, Wallace published his theory of the ratio method of determining prices in this book. Subsequent reference to the hog-corn ratio will always mean the relation between the price of hogs per 100 weight and that of a bushel of corn. The grade of hogs will be understood to be good to select. 
Pork production remained below the needed level, and pressure mounted for a change in the Food Administration's policy. Late in September 1917 Pinchot wired Wallace suggesting that Hoover might now be persuaded to adopt the ratio guarantee if hog producers were to demand it, and he urged the farm editor to call a meeting of his advisory committee to petition the Administration. Opposed to the idea, Wallace thought that such action "would give the daily papers a chance to say that the farmers are the one class of people in the country who are demanding excessive profits and who are threatening to reduce their production if they don't get them." Besides, he told Pinchot, Hoover was fully informed as to the wishes of hog producers and the views of the pork committee. Still, Wallace implied that he would be willing to call a meeting to discuss the ratio question if the Food Administration directly requested it. $^{4}$

Pinchot could understand Wallace's position. "But," he argued, "we are dealing with a man nervously overwrought, seeking to avoid action and sensitive to criticism." Pinchot assured his friend, furthermore, that he had Hoover's promise to adopt the pork committee's recommendations on the ratio guarantee. ${ }^{5}$ The farm editor was still reluctant to move on his own, however, and refused to call his group together. Failing to convince Wallace, Pinchot continued his campaign within the Food Administration, and Hoover finally issued an official request for a meeting of the pork committee. Held in early October 1917, the conference voted to recommend establishment of a minimum guarantee on hog prices representing a 14:1 ratio, with no explanation for the increase over the 13:1 ratio originally suggested by Wallace's son. Echoing this decision, pork producers' meetings held in Kansas City and Omaha following the Waterloo session passed identical recommendations.

${ }^{4}$ Telegram, Wallace to Pinchot, Sept. 26, 1917; and Wallace to Pinchot, Sept. 26, 1917, Wallace Papers, Box 1.

${ }^{5}$ Telegram, Pinchot to Wallace, Sept. 26, 1917, ibid. When the two men next met, Pinchot showed Wallace Hoover's memorandum in which he promised to adopt the recommendations of the pork committee. Wallace to Pinchot, Dec. 11, 1917, ibid. 
Immediately after the Waterloo meeting, Pinchot was apprehensive about the possible adoption of the committee's recommendations. "If only we can get action," he wrote to Wallace. "This is the one matter for anxiety now." A discussion with the Food Administrator a few days later served to confirm his fears. Despite his earlier promise to accept the committee's advice, Pinchot fumed, Hoover had decided to reject the guarantee proposal and resort instead to exhortation by the President to bring about an increase in pork production. Pinchot regarded this as "the stupidest mistake in policy I have ever seen a man in high office make. . ." and could explain it only in light of Hoover's "deep-rooted antipathy to the producer, an antipathy which with the exception of a few individuals seems to color the whole Food Administration. .." He was at loss to comprehend "the blindness which permits a man in Hoover's position so completely to disregard the essential elements of the situation, and let his personal feelings play so large a part in a policy of the highest international consequence." So incensed was Pinchot that he resigned from the Food Administration a short time later.

But Pinchot, is his disgust with Hoover, had distorted the picture. In the same letter indicating that Hoover "seemed determined to break his word to me," he also mentioned that the Food Administrator intended to appoint a commission to study the price-ratio theory. The responsibility of this group would be to determine the current ratio between the prices of hogs and corn and to recommend what increase would be necessary to stimulate the desired production. A short time later, Hoover directed Wallace's advisory committee to appoint the commission. After an exchange of several letters in which Wallace attempted to extract a definite commitment on the guarantee proposal (Hoover remained shrewdly evasive), the farm editor finally called his committee together in Chicago on October 18. At this meeting the group named

${ }^{6}$ Pinchot to Wallace, Oct. 6, 1917, ibid.

${ }^{7}$ Pinchot to Wallace, Oct. 11, 1917, ibid., and Pinchot to Mark Sullivan, Feb. 24, 1921, Gifford Pinchot Papers, Manuscript Division, Library of Congress, Box 242. 
a study commission under the head of John M. Evvard, a member of the staff of the agriculture department at Iowa State College. "A foolish stunt," was Wallace's view of the move, "but I suppose Mr. Hoover thinks it wise to have such a report [as the commission would make] to fall back on."

Though not as vehement in his criticism as Pinchot, Wallace's irritation with the Food Administration was mounting. Agreeing with Pinchot that antipathy toward producers was part of the reason for the Administration's failure to act, he believed that Hoover's inability to understand the problem of encouraging marginal producers was just as important a factor. Iowa farmers could profitably market hogs at the current price, which represented a ratio of about 10:1, but they alone could not meet the demand for pork. If the Food Administration expected to attact a sufficient number of farmers into hog production, it would simply have to take stronger measures to increase the price ratio. Unfortunately, Wallace lamented, Hoover was incapable of grasping that fundamental fact.

Hoover, on the other hand, now claimed to have no authority to guarantee hog prices. The enabling act had specifically provided for the wheat minimum, he explained, but the Food Administration had neither the power nor the money to maintain a minimum on hogs. Meat packers, moreover, were unwilling to support prices on a voluntary basis. Thus the only action Hoover could see open to him was to continue the propoganda campaign and hope that farmers would respond to the call for greater pork production.

The Evvard commission met in Chicago on October 27 and submitted its recommendations to Hoover on the same day. Conceding that under normal conditions the laws of supply and demand should control price levels, the report declared that the emergency situation brought on by the war necessitated "definite artificial stimulus" to meet increased demands. According to the commission's findings, based on offerings at Chicago, a ratio price of 12:1 was necessary to cover the average cost of hog production, 13:1 to bring

${ }^{8}$ Wallace to Pinchot, Oct. 16, 1917, Wallace Papers, Box 1. 
production back to normal, and 14.3:1 to bring about the necessary increase. Its report therefore recommended that the Food Administration establish a guarantee ratio of 14.3:1 to go into effect Feb. 1, 1918, and a guaranteed minimum price of $\$ 16$ per 100 weight for the interim period. Although not an official member of the commission, Wallace's son did the statistical work on which its findings were based.

If Hoover had hoped to avoid commitment to a ratio guarantee, he received little comfort from the study commmission's report. Action now had to be taken either in the form of some type of acceptance or complete rejection of the proposal. The Food Administration's answer came on November 3 in a statement by Joseph Cotton, head of the agency's meat division, in which he stated that the Administration intended to use its vast influence over the hog market to raise prices. Its transaction as the sole purchasing agent for the Allies, American military, and Red Cross, Cotton explained, constituted a decisive factor in the market, and the Food Administration proposed to use this influence initially to prevent hog prices from falling below $\$ 15.50$ per 100 weight, "so far as we can affect them." As for hogs farrowed in the spring of 1918, Cotton continued, the Administration would "try" to stabilize the price at a ratio of 13:1, an action which would presumably be undertaken sometime in the fall of 1918 when these animals were ready for sale. "Let there be no misunderstanding of this statement," Cotton concluded. "It is not a guarantee backed by money . . . It is a statement of the intention and policy of the Food Administration which means to do justice to the farmer." ${ }^{\prime 9}$

Although not entirely satisfied with Cotton's statement, Wallace regarded it as the most encouraging sign yet from the Food Administration. To be sure, it fell short of the complete and immediate application of the ratio formula which the farm editor desired. But he was satisfied that, if Hoover would use fully the power of his office to implement the announced policy, the result would be a substantial increase in hog prices.

${ }^{9}$ Prices of Hogs (U. S. Food Administration, 1917). 
Throughout the rest of 1917 and into the next year hog prices stayed above the $\$ 15.50$ minimum but made little advancement from the previous fall. When it became evident that the anticipated price increase was not materializing, Wallace wrote to Cotton warning of continued meat shortages and began to attack the Food Administration in the columns of Wallace's Farmer. Hoover felt that the farm editor was being unfair in view of "my whole-hearted adoption of the principle and figures of the Everard [sic] commission and our earnest efforts to carry it [sic] out to the letter ..."10 As Wallace pointed out to him, however, he had adopted the commission's recommendations merely "in part" and then only after a costly delay for the producers. And in regard to the really critical question of the 13:1 ratio, he reminded Hoover, "nothing has been done to carry it out for the very simple reason that you did not undertake to apply it until next fall." Challenging Hoover's contention that the Food Administration was attempting to carry out the principles of the Evvard report, Wallace retorted that "you have given intellectual assent to the soundness of these principles but you have failed to apply them."11

March 1918 saw the appointment of another study commission, this time selected by Hoover. With the exception of Evvard, none of the members had served on the earlier commission. Regarding the creation of the new group as something of "a joke," Wallace maintained that its purpose was to mislead farmers into thinking that the Food Administration intended to do something in their behalf. Although it met several times throughout the spring and summer of 1918, the commission issued no statements. Meanwhile, Wallace kept up his pressure on the Food Administration.

Finally, when spring-farrowed hogs were beginning to enter the market in September, the new study commission published its first report, relative to Cotton's statement of the year before. Applying the 13:1 ratio formula to the average price of corn at the country markets in "the leading hog states," it declared $\$ 15.50$ per 100 weight to be the price which

${ }^{10}$ Hoover to Wallace, Feb. 3, 1918, Wallace Papers, Box 1.

${ }^{11}$ Wallace to Hoover, Feb. 11, 1918, ibid. 
the Food Administration must endeavor to maintain in order to honor its commitment of the previous November. On the surface the report appeared to accept the findings of the Evvard commission as a basis for determining prices, but there was one important difference. The ratios of the earlier report were to be applied, not to the average price of corn at the country markets of the leading hog states, but to offerings at Chicago. Since Chicago corn prices were always somewhat higher than at the country markets, hog prices figured on the basis of the Evvard report would have been nearly three dollars higher than the $\$ 15.50$ recommended by the second commission.

Hog producers had hardly comprehended the significance of this development when the Food Administration announced its intention to abandon the ratio formula entirely. In a report in late October the study commission explained that due to the sharp drop in corn prices with the approaching end of the war, the ratio method would work to the disadvantage of pork producers. Confident that hog raisers did not want their incomes tied to declining corn prices, the commission recommended that the Food Administration return to the policy of supporting a minimum price. Hoover quickly adopted the new proposal.

Wallace was furious, charging that the Food Administration had deliberately deceived the farmers. He complained that hog producers had increased output in response to Cotton's statement. But when it came time for the Administration to do its part, it avoided its commitment through the transparent subterfuge of changing the corn-price basis. And, if this were not enough, it dropped even the subterfuge a month later and bluntly told farmers that no attempt would be made to maintain the promised ratio.

Although the Food Administration used its influence to bolster hog prices in 1918, Wallace's charges were wellfounded. Cotton's statement, it is true, did not specifically accept Chicago corn prices as the basis for the ratio formula. But Hoover's "whole-hearted adoption of the principle and figures of the Everard [sic] Commission" represented an implicit 
acceptance-in view of the fact that the commission report clearly stated that its findings were based on Chicago prices. The reasons given by the Administration for abandoning the ratio formula were also specious. While there was a drop in corn prices in October 1918, the minimum hog prices which Hoover's agency endeavored to maintain from that month on always represented less than a 13:1 ratio, at least at Chicago offerings. And this, after it had stated that the ratio formula was being dropped because it would be unfair to producers. It is interesting to note that hog prices did not reach a 13:1 ratio level until after the Food Administration had abandoned efforts to support prices in March 1919.

Hoover complained that farmers had misinterpreted Cotton's announcement to be an absolute guarantee when it was only a statement of policy which the Food Administration would attempt to carry out. This was true of many producers. Despite numerous attempts to correct the misconception, there was a general belief that the policy on hogs had the same status in law as the wheat minimum. Still, while this misunderstanding led farmers to criticize Hoover unfairly, it by no means justified or even explained his deception in changing the corn-price basis when it came time for the Administration to fulfill its commitment.

The controversy had an unfortunate effect on the relationship between the principal protagonists. Wallace and Hoover developed strong antagonisms toward each other, antagonisms which continued after the termination of World War I. In 1920, when Hoover's name was mentioned as a possible presidential candidate, the farm editor launched a campaign against him, rehashing all of the arguments against the Food Administration's handling of the hog matter and urging farmers to unite in opposition to any move to place Hoover in the Presidency. "It would be a real misfortune," Wallace wrote to a friend, "if he [Hoover] should succeed in securing the nomination in either of the political parties." $\mathrm{He}$ felt obliged to use his farm journal "to warn our readers against a possible candidate for nomination whom we regard as 
distinctly hostile to their interests." ${ }^{{ }^{12}}$ Wallace's editorials provoked a discussion in Congress and forced Hoover to send a letter to the Senate in his own defense. Less than a year later the two adversaries were to find themselves members of the same cabinet, and their fight during the war was in part responsible for the renewed bitterness which developed between them over federal policy and action in the Harding and Coolidge administrations.

\section{"TEN CENTS A MILE AND A FENCE RAIL" Stagecoaching In Iowa}

\section{by LeRoy Pratt, President \\ lowa Society for the Preservation of Historic Landmarks}

The earliest settlers in Iowa either provided their own transportation-horses, oxen, and wagons-or came up the Mississippi River, landing at Keokuk, Fort Madison, Burlington, Bloomington (now Muscatine), Davenport, Lyons or Dubuque. These pioneers found work, started a business, or went inland to stake out claims.

The heavy wagons of the settlers cut deep ruts into the tough prairie sod, along the tops of ridges and around the marshes. As others followed in the same paths, wheels gradually wore the trails deeper, to form long crooked scars across the land. These were to become the highways of the new country. Ditches were plowed beside the roads and bridges built to span the streams. Road building was one of the earliest and most important tasks of local government.

During the first years of the territorial and early state period, Iowa travelers depended largely on water transportation. The rivers were favored as the cheapest and easiest means of travel, but they did not go everywhere. Stagecoach service was extended slowly as a second type of public transportation, as settlement spread to the interior. The service

${ }^{12}$ Wallace to H. S. Irwin, May 18, 1920; and Wallace to A. V. Mather, April 21, 1920, ibid., Box 2. 
Copyright of Annals of Iowa is the property of State of Iowa, by \& through the State Historical Society of Iowa and its content may not be copied or emailed to multiple sites or posted to a listserv without the copyright holder's express written permission. However, users may print, download, or email articles for individual use. 